\title{
3. Platform capitalism - towards the neo-commodification of labour?
}

\author{
Petar Marčeta
}

\section{INTRODUCTION}

The aim of this chapter is to elaborate a theoretical reconceptualisation of platform capitalism, and specifically labour mediating platforms (Srnicek 2016), from the perspective of the commodification of labour. We will argue that this perspective, firstly, brings us closer to answering the often-posed question of what is old and what is new in the platform economy, and, secondly, helps us understand the implications of these developments as well as the potential futures they could usher in.

Previous research has identified the process of platformisation as a form of commodification of labour (Aloisi 2015; Bergvall-Kåreborn and Howcroft 2014; Boes et al. 2017; Wood et al. 2019). Early in the development of platform capitalism, legal scholars sounded the alarm, warning us that platform arrangements lead to a misclassification of workers, who, without the protections and rights afforded to employees, become 'commoditized' (Aloisi 2015). Pure online 'crowdwork' was also scrutinised early on, with some accounts showing how the physical separation of workers and the fragmentation of their tasks sets the stage for the commodification of labour (Bergvall-Kåreborn and Howcroft 2014). Looking at the wider picture of the technology used, there was also a discussion about how the emerging 'information space' becomes the launchpad for the expansion of capital into different spheres of life (Boes et al. 2017), hence the possibility of understanding the impact of platform technology across the board has opened up. Finally, in the most theoretically elaborate use of the concept of commodification, Wood et al. (2019) argue that despite the strong embeddedness in networks, platform work is essentially a hyper-commodified form of labour, exposing workers to insecurity and precarity.

We wish to build on these perspectives and their linkages, but in order to answer our questions, we ought to unpack the concept of commodification stressing its importance for the process of accumulation and its relation to the 
concepts of Landnahme and the reserve army of labour. To this end, we will draw on theoretical insights from Marxism, the work of Karl Polanyi, and German critical sociology, articulating them with the booming literature on 'platform capitalism' (Srnicek 2016) and 'surveillance capitalism' (Zuboff 2019) which stresses the importance of data collection and analysis.

In order to form a comprehensive link between the theoretical conceptualisation of labour as a commodity and the observed realities of platform labour, in this chapter we will introduce the concept of neo-commodification, which we define here as the data technology-driven commodification of labour, which encompasses both the recommodification of labour through the undermining of the standard employment relationship (SER) and the expansive commodification of previously uncommodified labour.

Our argument will unfold as follows. Firstly, we examine the concept of commodification from both Marxist and Polanyian perspectives. We will try to show the relationship between the derived concepts of decommodification and recommodification and some critiques thereof. Secondly, we will develop the concept of neo-commodification, by investigating several of its elements: the negation of the SER, dismantling of social protection systems and, finally, the use of data and control mechanisms. Finally, in section 4, we will look into some of the implications of these trends, again engaging Marxist and Polanyian perspectives in a dialogue in order to better understand the institutional responses and struggles arising around the process of platformisation.

\section{THE CONCEPT OF COMMODIFICATION}

In this section we will look into the ways Marxist and Polanyian inspired ideas of commodification can be brought into dialogue, allowing us to study not only how institutions develop around and against the commodification of labour, but also how the process of capital accumulation seeks out new avenues, both within its current domains and beyond.

\subsection{Labour as a Commodity}

For the purposes of this chapter it is sufficient to trace the origins of the idea of commodification of labour to the work of Karl Marx as it offers a starting point from which to understand the systemic importance of the constitution of labour power as a commodity and opens up possibilities for a historical analysis of labour. While there is much more to be said about Marx's understanding of labour power as a commodity, here we are focusing on a particular interpretation which found its way to Polanyi, and later Esping-Andersen.

What looking back at the project of Marx reminds us of is the unique character of the capitalist mode of production (Harvey 2015, p. 41). Specifically, for 
the process of capital accumulation, the acquisition of the means of production and the purchase of a commodity which has the unique ability to create value are necessary (Marx 1976, p. 271). The only such commodity is labour power - i.e. human capacity to labour. In order for the purchase of labour power to be possible, a market must be in place in which capital and labour encounter each other as buyers and sellers, respectively. For this, Marx argues, two conditions need to be met. Firstly, 'labour-power can appear upon the market as a commodity, only if, and so far as, its possessor, the individual whose labour-power it is, offers it for sale, or sells it, as a commodity' (Marx 1976, p. 271). Secondly, the worker must be forced into such an exchange because he is not the owner of the means of production himself and has no other means of subsistence. ${ }^{1}$ Hence, from a Marxist perspective, the commodification of labour power is a necessary precondition for the accumulation of capital, which in turn is the imperative of capitalist production (Burawoy 2010).

The other common source for the concept of commodification of labour is the work of Polanyi (2001). Initially working from a Marxist standpoint, his work has diverged, and the relation between the work of these two classical approaches remains disputed (Block 2003; Burawoy 2010). Polanyi's interest rests not in the process of capital accumulation as such, but in the development of the market economy which spreads through the process of commodification. Commodities are here defined simply as goods which are made in order to be sold on the market. However, the development of market society encounters a problem with commodifying labour, land and money, which Polanyi famously characterises as 'fictitious commodities' since they are in their essence not produced in order to be sold. Labour, he further argues, is 'another name for a human activity which goes with life itself', it is inseparable from its bearer and cannot be 'stored or mobilized' (Polanyi 2001, p. 75). Therefore, if the market was the 'sole director of fate' of human beings it would bring about the destruction of society (Polanyi 2001, p. 76). Hence the dual development of market society - on the one side expansion of markets and the commodity form, on the other the development of institutions counteracting this trend, protecting society from those very markets.

In conclusion, Marx sought to explain how capitalism is dependent on the commodification of labour power - a commodity which is peculiar in the sense that it is tied to the fortunes of those offering it for sale - the workers. Polanyi further develops this idea of labour as a fictious or false commodity, convincingly arguing how the drive to commodify that which cannot be commodified leads to a destruction of society. What is important to stress at this point, is that both Marx and Polanyi point towards the asymmetrical power relation at the heart of the commodification of labour. For Marxist theory this is a source of permanent struggle and crisis around the accumulation of labour (Harvey 
2015), while Polanyi builds on this idea of an asymmetrical power relation and how it is altered by the countermovement of society and its institutions.

\subsection{From Decommodification to Recommodification}

Polanyi's work provides a foundation for understanding the early rise and spread of industrial capitalism, but also the ways in which society reacts, by embedding the market and preventing it from self-destruction. Building on this idea of a dual movement (marketisation on one side, and the countermovement on the other), the idea of decommodification, or reversing the trends of commodification has been developed in the study of institutions. It is widely accepted that the most developed form this process has taken are the post-war Western capitalist countries. Here we can identify two institutions through which decommodification is enacted: the labour contract and the welfare state.

The labour contract is seen as a specific institution based on the recognition of labour as a fictitious commodity - as such, it differs from a commercial contract. Crucially, labour contracts are supposed to guarantee a minimum level of autonomy to the bearers of labour power (Offe 1985, p. 20). Hence, it distorts the 'pure market' relationship, and forms the basis of what came to be known as the standard employment relation (SER). As Rubery et al. (2018, p. 510) summarise: 'the essence of the SER is found not in its habitual form of full-time permanent work but in its substantive protections against a pure market relationship, jointly provided by employers and the state through employment rights and social protection'. Finally, the structural importance of this institution is that it forms the basis of a system of industrial relations, which regulates the power balance between labour and capital (Offe 2011, p. 190).

The second important institution is the welfare state. Famously, Esping-Andersen (1990, p. 37) defined decommodification as the 'degree to which individuals, or families, can uphold a socially acceptable standard of living independently of market participation'. It is social protection, provided by the welfare state, in its various forms, from pensions, unemployment and sickness benefits to healthcare and housing, which enables individuals and families to uphold this living standard. If the labour contract emerges out of the fictitious character of labour as a commodity, and the SER regulates the struggle between labour and capital by defining responsibilities, the welfare state is the institutional embedding of these relationships. But the welfare state, as Fudge (2017) reminds us, does not appear naturally - it is a result of class struggle embedded in collective representation.

History has shown how fragile the compromise which emerged from this struggle has been. As Streeck argues, it didn't take long before it was challenged by the forces of capital, starting in the 1980s (Streeck 2017). This 
process is conventionally referred to as the age of neoliberalism (Harvey 2007), and while it is tempting to regard the ensuing process as that of deregulation of capitalism, analytically it is much more fruitful to think of this era as that of the re-regulation of capitalism (Standing 2007) in such a way to enable a stronger marketisation of societies. If welfare state capitalism was underpinned by the idea of decommodification, neoliberal capitalism unleashed its opposite, known as 'administrative recommodification' (Offe and Keane 1984, pp. 122-4). This term, introduced by Claus Offe, refers to government strategies aimed at bringing wider sectors of the population into a relationship of direct dependency on the market, therefore reversing the trend of decommodification. This term was then further elaborated by Greer who defines it as 'any institutional change that reinstates the discipline of labour market competition on workers, whether in or out of work and whether through reforms to welfare states, industrial relations, or labour markets' (Greer 2016, p. 165). The process of recommodification hence affects both the SER, which is loosened or bypassed in different ways, and the welfare state, which is increasingly being re-regulated into different forms of workfare states through activation policies (Crouch 2019; Greer 2016; Rubery et al. 2018). The latter refers to a shift in the basic logic of the welfare state, from universality to greater conditionality of benefits. In other words, instead of limiting the dependence of individuals on market mechanisms, workfare and activation policies are supposed to encourage better integration of individuals into labour markets.

Finally, this process has unravelled through the destruction of the system of collective representation and industrial relations, either through the direct destruction of trade unions (Harvey 2007), or through the abandonment of institutions which were set up to limit the power of capital (Baccaro and Howell 2017).

\subsection{Critique of the Decommodification/Recommodification Perspective}

Various critiques of the perspective discussed above have been developed over time, but for the purposes of this chapter it is sufficient to focus on how the Polanyian perspective can be revised. One critical reinterpretation of Polanyi's theory comes from the feminist perspective of Nancy Fraser (2014). Her argument, simply put, is that the protective mechanism that society develops against commodification is itself riddled with domination, namely the domination of women by men. The fictitious commodification of labour rests on the non-commodified labour that sustains it, this labour being done in the context of the sexual division of labour. However, as the market expands it commodifies this labour as well. On the one hand this has an emancipatory character because it undermines the gendered relations of domination, but on the other 
hand it commodifies the life chances of those performing it (Fraser 2014, pp. 546-9). The importance of this theoretical intervention lies in the way Fraser attempts to encompass forms of labour which have traditionally been unpaid (thus not commodified and 'invisible') but which are enforced through domination. This helps us theoretically explain the constraints and incentives which commodify new types of labour, thus effectively expanding the market dependency of certain categories of population (women, youth, elderly, etc.).

Indeed, as Standing (2007, p. 70) has argued, the era of welfare state capitalism 'involved the decommodification of male labour' and the advancement of a system of entitlements based on the norm of SER. This means that the process of decommodification was never complete and, hence, the concept of recommodification is only partially relevant. The shortcoming of focusing on this 'pendulum like' (Wood et al. 2019) movement between re- and decommodification can be seen as a sort of 'false optimism' (Burawoy 2010). As Burawoy argues, the illusion of the Polanyian perspective that society can completely fight back and embed the market is a consequence of forgetting the capitalist imperative of accumulation. This does not mean that we should forgo the study of decommodification - rather, it means that we should include in our perspective the way in which commodification persists and seeks out new avenues. For this, we will examine the concepts of Landnahme and the reserve army of labour.

Returning to Marx, we have seen how at the most basic level, commodification is a necessary prerequisite for the accumulation of capital. In order to put this issue into a more dynamic perspective, we will engage with the concept of Landnahme (Boes et al. 2017; Dörre et al. 2015; Harvey 2015), defined here as process of expanding commodification to decommodified as well previously uncommodified aspects of life in order to sustain the accumulation of capital. Importantly, the process of Landnahme has two dimensions (Boes et al. 2017). Firstly, internal Landnahme refers to reinstating or accelerating the logic of commodification further. A good example would be the previously discussed developments of recommodification, such as the workfare policies which force further labour market discipline. In a European context this could be illustrated by the increased conditionality of benefits, which forces job seekers to accept any kind of job, even if it involves unsatisfactory working conditions.

The second dimension is external Landnahme, which refers to the subsumption of labour outside of the mode of production (including those whose labour was not commodified before, and building up a reserve army of labour). This basic logic of expansion has been theorised and researched in different ways, but here we might invoke the work of Beverly Silver (2003) who looked into the ways by which capitalism tries to overcome its crises by moving production geographically (spatial fix), or through the discovery of new technology. Hence, an example of the external dimension is the migration of production 
to areas previously 'outside' of the capitalist system. Again, in a European context, this could be illustrated with the example of moving production from Western to Eastern Europe, where labour costs are lower and organised labour is weaker, during the 'transition' of the 1990s. These two dimensions are interrelated, and present different strategic options for capital, hence different combinations of the two can be observed at any given historical moment (Dörre et al. 2015).

Marxist theory offers another related term which can be helpful for understanding the labour market dynamics we wish to study; namely, the mechanism of the reserve army of labour. This refers to the "relative surplus population" generated by and needed by capitalism, whose standard of living is below that of the working class and whose members are available for exploitation in expanding areas of the economy' (Greer 2016, p. 165). Hence, the mechanism of the reserve army of labour serves to lower the costs of labour in new areas of capitalist expansion and can thus be seen as an accompanying process of Landnahme.

In conclusion, if used carefully, the concept of the commodification of labour can help us understand not only the changes that the SER and welfare states have been experiencing (internal Landnahme), but also the drive for further accumulation beyond embedded labour (external Landnahme). In the following section we will argue that the development of platform capitalism accelerates and opens up possibilities for both of these aspects, thus leading to what we shall refer to as the neo-commodification of labour.

\section{TOWARDS THE NEO-COMMODIFICATION OF LABOUR}

In order to understand the historical embeddedness of platform capitalism, it is useful to briefly look into the historical context in which it first appears. Pinpointing the emergence of platforms usually begins with the post-crisis period of recovery - the period after 2008 (van Doorn 2017). It is argued that the financial crisis and subsequent recovery created a pool of unemployed ready to engage in any kind of work - fertile terrain for the development of hyper-flexible work offered by platforms (Schor and Attwood-Charles 2017, p. 7). Coupled with that were certain business trends, such as making high risk-high yield investments into the tech sector (Srnicek 2016, pp. 32-3). Our analysis shouldn't stop there, as the existing literature also stresses the importance of situating platforms in certain longer-term trends. Both Srnicek and van Doorn start their analysis in the period which begins at the turn of the 1980s (Srnicek 2016; van Doorn 2017) which in the previous section we saw as the period in which post-war settlements in Western capitalist democracies were dismantled through the process of recommodification. Platform 
capitalism is thus often seen as an extreme manifestation of the ideology and practice of neoliberalism (Murillo et al. 2017). In this section we will further develop this idea, by delving into the ways platformisation can be understood as neo-commodification. We will start by exploring what can conceptualised as the internal Landnahme of platform capitalism, the negation of the SER and social protection. Next, we will consider the external Landnahme of platform capitalism, enabled by data collection and connected control mechanisms. These two processes together form the specific combination of old and new processes which we will denominate the neo-commodification of platform capitalism.

\subsection{Platforms and the Negation of the SER}

The existing literature overwhelmingly argues that one of the key issues surrounding labour organized through platforms is the misclassification of workers as self-employed (Donini et al. 2017; Fabo et al. 2017; Garben 2017; Kilhoffer et al. 2017; Scholz 2017; Sprague 2015; Todolí-Signes 2017). This question, however, has several layers, and in light of the theoretical considerations from the previous sections, we can approach this issue as a question of the degradation of SER.

From a legal perspective this turned out to be a challenging question of applying 'tests' to decide the nature of the relationship between platforms and contractors, i.e. deciding whether a person working through an online platform is an employee or not. The application of these tests however, proved to be rather controversial, with diverse and sometimes contradictory rulings in different countries (Cherry 2016; Zekic 2019). Some cases, particularly when involving Uber or food delivery platforms, as the quintessential and highly visible platform companies, have attracted considerable media attention - as was the case when workers for Foodora in Australia (Zhou 2018), Deliveroo in the Netherlands (Andersen 2019) and Uber in the UK (Osborne 2016), in France (ETUI 2020) and somewhat symbolically, in the birthplace of platform capitalism, the state of California (Paul 2019) were all declared to be employees. Nevertheless, academic debates have questioned the adequacy of existing regulation and whether new categories of workers should be devised (Garben 2017; Sprague 2015; Todolí-Signes 2017). But as some have noted before (Cherry 2016), beneath the surface of these legal intricacies are very important questions about the contemporary state of labour, hence the discussion should not stop there.

Some researchers have noted how labour contracts in the platform economy have been substituted with Terms of Service agreements, which grant platforms immunity and relieve them of employer responsibilities (van Doorn 2017, p. 902). As Crouch notes about gig-work companies: 'they speak as though 
the gig turns the employment relationship into a truly equal contract, on shorn of the hierarchical implications of the employment relationship and therefore not requiring the balancing provisions of labour law to protect workers' (2019, p. 15). In other words, this sort of 'take-it-or-leave-it' arrangement reflects precisely those unequal power relations between seemingly 'free' agents on the marketplace, which Marx described long ago.

Furthermore, the platform economy is plagued by another, one might say, discursive element which could be rather unique. Namely, platform companies are known to have often mystified their role as employers, describing themselves instead simply as 'intermediaries' on the market. This is also recognisable in the official discourse ${ }^{2}$ of the platforms, when they refer to themselves as 'tech companies' (Sundararajan 2016, p. 157) rather than transport, courier, rental, etc., companies. In line with this strategy is the lack of participation of platform companies in representative business organisations (in some cases there is even a conflictual relationship between platforms and organisations representing businesses in danger of being 'disrupted') which might engage in collective bargaining (Kilhoffer et al. 2017). Platform companies, nevertheless, can be organised in a different way - focusing attention on lobbying activities to influence regulation in their favour (Scholz 2017, p. 46), rather than taking up their role as a negotiation partner vis-à-vis their workers.

\subsection{Challenging Social Protection Systems}

Closely linked with the issue of SER is the platform workers' social protection coverage. Since, as mentioned, the connection between SER and social protection is in most cases rather strong, misclassified platform workers will often miss out on different kinds of protection, most notably unemployment and sickness benefits (Cherry 2016). In Europe, for example, workers in non-standard working arrangements and self-employed workers are rarely covered by any contributions-based benefit (Bouget et al. 2017). It is clear how the logic of labour platforms fits this trend: shifting the risks and responsibilities from employers to workers, ${ }^{3}$ who are seen as supposedly free actors, engaging in a voluntary market exchange.

This lack of social protection coverage is clearly observable in data from the 2017 ILO survey, for example, which shows that only 35 per cent of platform workers worldwide had a pension plan, 37 per cent had some sort of social insurance and 29 per cent received government assistance (Berg et al. 2018, p. 60, see also Berg and Rani in this volume). A closer look at this data is even more revealing - for the majority of those covered by some protection, platforms are not the major source of income. Concurrently, the same survey reveals that the main motivation for participating in platform work is to 
supplement low income from the primary job (which might offer some social protection scheme).

Thus, we can conclude that while platform labour in its purest form bypasses or even erodes social protection systems which are not designed to cover solo self-employed workers, it also presents a strategy to 'add up' a decent income through extra work - platform workers can thus be seen as a prime example of 'hybrid self-employed', where the boundaries between employment and self-employment are blurred - both in terms of their legal status and the discourse surrounding them (Murgia et al. 2020; Murgia and Pulignano 2019). Crucially for our topic, this sort of arrangement is not a system anomaly - it means that platform labour not only embodies the tendencies of recommodification but it also accelerates the workfare agenda, by imposing a market solution to market problems.

\subsection{Data and Control}

So far, we have shown how the tendency of platform companies to annul the SER, and subsequently also what is left of the decommodifying social protection institutions, fits perfectly with, and enhances, the recommodification agenda. In fact, one would be forgiven for observing that many of these issues fit the discussion on non-standard employment and labour recommodification so well, that they do not merit the status of a separate research topic. However, as explained earlier, there is a further element in the story about platforms, which showcases their novelty - that is, the use of technology which enables the commodification of labour.

Platform technology depends on the collection and analysis of data (Srnicek 2016). Naturally, the more data there is, the more successful the model is, as it rests on the principles of the economy of scale. This means that there is a natural tendency to monopolise data, but also to seek out new areas where it can expand. The development of smart technologies opened up these areas as never before, thanks to the data collection possibilities of devices such as the smartphone (Greenfield 2018). Crucially for labour, this principle holds for both on- and offline work - in both cases it is crucial to collect as much data as possible in order to assign and coordinate tasks, and manage and control the workforce. Commentators have noted how this information space opens up the area for this new external Landnahme of hyper-mobile capital and labour (Boes et al. 2017). What we then see is that, through the collection of data, the work and private spheres are merged into one - allowing the logic of the mode of production to expand from one to the other. Here lies the crucial aspect of platform capitalism which deserves attention and points towards its exceptionality. Through their reliance on expanding data, platforms present strong 'market making' possibilities (Drahokoupil and Piasna 2017), or, in 
line with our approach, strong commodification possibilities. If we return once more to Marx, we can see this digital data infrastructure as the perfect marketplace where labour and capital can meet. But the workers themselves, with the above-described merging of work and leisure, can become fully available for work or, in other words, fully commodified.

Going further, we can argue that by means of internal Landnahme, platforms recommodify labour through the destruction of SER and social protection. However, critics have long argued that there are sectors of society performing work which has never been commodified, and, consequentially, could never have been recommodified or decommodified. Such is for example the care work predominantly performed by women, or various sorts of 'grey labour' performed by migrant workers who would otherwise face difficulties in the labour market.

This is fertile terrain for platforms to operate in: through external Landnahme, they also further the commodification of labour - by creating a fictious, global labour market. This principle can be applied to both on- and offline labour platforms. With the latter the competition is truly global, but with the former it similarly unleashes the potential for all unemployed or underemployed workers to become a sort of 'hybrid'. This is where we can once again evoke the concept of the reserve army of labour - if an internet connection is all it takes to gain access to a global labour market, the supply of labour can expand to levels never seen before, far outstripping the demand, as reported in research (see e.g. Berg and Rani in this volume).

Finally, some influential recent accounts of these trends argue that the commodification of data has a logic of its own, which is to predict and influence behaviour and find a way to monetise it (Zuboff 2019). When it comes to labour platforms, these behavioural nudges, coupled with tight metrics and the described immunity granted through Terms of Service agreements, allow platforms to wield unprecedented control over their workforce (Kalleberg and Dunn 2016; Moore and Joyce 2019; van Doorn 2017).

In conclusion, the combination of internal and external Landnahme, coupled with an algorithmic control system, expresses the potential of platforms to accomplish a neo-commodification of labour. However, Marxist and Polanyian accounts of commodification have certain implications - for Marxists they form the essence of the class struggle, by pointing us towards the essential contradictions underpinning labour relations. This is where a Polanyian perspective is a useful next step, as it helps us understand the variety of institutional outcomes of these contradictory forces and processes. In the next section we will take a look at both of these approaches. In this manner, we can see what kinds of outcomes this neo-commodifying potential of platforms can have. 
So far, our argument has unfolded in such a way as to balance out the claims of the novelty of platform capitalism and those which view it as 'old wine in new bottles'. We have argued how, despite fitting perfectly with some old commodification and recommodification trends, platforms open up spaces for a neo-commodification of labour on a global scale, thanks to their use of technology, data and elaborate control mechanisms.

In this section we will look into developments occurring in response to neo-commodification. As has been the case so far, we will do this by articulating Polanyian and Marxist perspectives. Firstly, we will take a look at how, rather than expecting a spontaneous stabilisation of the platform model, we ought to take into account the institutional re-embedding of platforms. However, as we will see shortly, there have been limited and very diverse responses to this problem. We will offer several potential explanations as to why these developments have been slow and varied, again focusing on the combination of novel and old practices in platform capitalism. Secondly, we will examine how the conflicts around neo-commodification elicit responses from both old and new actors.

\subsection{Institutional Responses and Embedding Platform Capitalism}

With the rapid expansion of platform capitalism, and given its reliance on venture capital and its short-term, high-risk, high-yield nature, questions have been raised about its stability and limits. For labour, the question is how much we can expect this neo-commodification to spread. Colin Crouch (2019, pp. 19-20) for example, while maintaining that the future of platforms is still open, argues that the specific balance of stability and flexibility offered by platforms might shift in favour of the workers, once a need arises for platform companies to guarantee more commitment from its labour force. Indeed, Crouch claims that certain companies are already offering certain fringe benefits to its 'self-employed' workers. We might further add that in the context of the pandemic crisis of 2020, this kind of countermovement on the part of capital might increase, as shown by some recent examples where platform companies have been offering forms of insurance to their workers (Marshall and Gregory 2020; Rana 2020).

But here, caution is advised: it is by no means unreasonable to question where the limits of the platform model lie; however, the limits to commodification are set by organised labour fighting back, holding ground and imposing standards, rather than capital's inherent need for stability. Thus, in order to better understand the future of platform labour and neo-commodification, we 
ought to look into the ways in which it has been incorporated into the institutional landscape, and also how these developments spark conflict.

The introduction of labour platforms in different contexts has mostly provoked a conflictual response. There is a notable diversity of approaches to regulating platform businesses, and labour issues have often been dealt with on a case-by-case basis, as shown earlier. Existing literature provides several examples of these developments.

The example of Uber is again paradigmatic. Thelen (2018) reports how the arrival of Uber always provokes a strong response from existing actors, yet the outcomes of these responses tend to diverge quite quickly. The regulatory approaches to taxi transport can be summarised in the following way: deregulation (USA), defence of existing regulation (Germany) and adaptation (Sweden). Interestingly, Thelen offers an explanation which focuses on how coalitions between different actors are formed to influence regulation, especially stressing the importance of consumers in the case of the USA. Here we can once again invoke the discursive power of platforms which, as Thelen argues, manage to present themselves as champions of innovation, making their regulation seem unpopular with the electorate.

An even stronger example of how governments promote the platform discourse is seen in Japan. As Shibata (2019) argues, the conservative government in Japan has framed the 'gig-economy' as an answer to some of the widely perceived societal problems, such as the lack of work-life balance and low participation rates of women in the labour market. Hence, the official government discourse promotes the gig economy as a way to bring more of the population into employment, and also promotes the familiar discourse of 'freedom' to perform paid work at any time (Shibata 2019, pp. 10-12).

In other cases, the aforementioned coalition between consumers and platforms is reversed, as Thelen (2018, p. 947) shows with the example of Germany, where a strong response from regulators (with a wide political consensus) and national-level taxi associations, managed to portray Uber as a threat to the public interest and safety. This response has been successful; as a result Uber offers a very limited service in Germany, while adhering to existing regulation.

Specific issues also arise around the questions of misclassification and social protection. Garben (2017) identifies four theoretical options to tackle this issue. First is the option of applying or extending existing regulation. Secondly, a new category can be devised, between employment and self-employment. Thirdly, social protection and employment status can be decoupled. And, finally, a special category can be devised just for platform workers. The actual applications of these categories are not yet so clearly distinguishable. The UK represents the closest example of the second approach. UK law recognises a category of 'worker' who has less protection than proper 
employees, but more than the self-employed. Even here, however, the application of this category to platform workers has not been straightforward, and court cases have been initiated (Garben 2017, p. 42).

With regard to the option of applying current regulation, a celebrated example of institutional embedding is the case of Nordic countries, where the problems of misclassification seem less salient, and there are even examples of collective agreement coverage (Dølvik and Jesnes 2018; Jesnes et al. 2019; Johnston 2020). According to research conducted by Jesnes (2019), some platforms in Norway have taken a distinctive approach, through the development of what she calls the 'hybrid' platform model. Here, platforms combine marginal part-time contracts and more stable employment relations, rather than self-employment. The explanation provided is that the existing regulation as well as pressure from the trade unions and regulators led to this outcome.

There are, however, two sides to this development. On the one hand, Jesnes argues that the hybrid model is a way to 'appease regulators and social partners' (2019, p. 70), but the actual outcomes are still far from the norm of SER and can lead to precarity, and as such can be detrimental to labour standards in general. On the other hand, one might argue that this is still a more favourable outcome than a complete disregarding of regulations and, since the platforms become a part of the industrial relations system, it could allow trade unions to exert more pressure in the future. In any case, it is telling that this example is an exception, rather than the rule, for the expansion of platforms. It is a rather specific context in which the institutions are strong enough to embed the platforms so quickly. Other examples point towards the difficulties of slowing down neo-commodification, where it more openly breaks out into disagreements between social actors, as we will see shortly. The important conclusion here should be that the disruptive effects of neo-commodification will not trigger a spontaneous re-embedding or the introduction of neutral policy but will be the subject of a power struggle between different actors.

Based on the discussion so far, we can conclude that there are several commonalities with regard to the impact of platforms on institutions and their ability to embed them. Nevertheless, these common pressures have resulted in a variety of outcomes.

Firstly, the platform business model itself is based on the idea of disruption or finding and taking advantage of grey zones of regulation (Söderqvist 2017; Thelen 2018). However, as we have seen, in some cases these grey zones have been eradicated quite quickly, with platforms being forced to adhere to existing regulation, or adapt their business to satisfy the social partners, as in the case of the Nordic countries.

Secondly, as mentioned earlier, a strong, and indeed unique, trait of the platform model is its discursive mystification. This mystification frames the debate around platform labour as a discussion between the technophiles and 
technophobes, and allows platforms to use their popularity with consumers, but, as we have seen, it can also be used by governments as part of a wider agenda of recommodifying policies. However, this is also a contested terrain - it is by no means unavoidable that the discussion is framed like this, as the example of Germany and Uber shows. In fact, the visibility of the platforms, and their responsibilities towards consumers, can focus public attention on these issues, and as we will see this opens up space for specific trade union strategies.

Finally, as the platform model challenges the positions of existing social actors, the response it incites will depend on the power resources and strategies of these actors. In this sense, while the first two sources of diversity in response, namely the capacity for disruption and mystification, are quite unique to platforms, the third one, its conflictual nature, is an ample illustration of how platformisation fits into the struggles around the development of non-standard employment relations.

It is worth noting that these developments are in a fairly early stage. As the disruptive effect of the apparent innovation of platforms fades, we might expect to see the consolidation of several distinguishable approaches. In any case, it is important to stress that there may arise a variety of institutional arrangements regarding platforms - there is not a single key to the impact of platforms, as it depends on contexts and actors. This point is worth keeping in mind, as it suggests that technology is not a force for the convergence of institutional systems around the world; rather, it highlights wider issues facing institutions of contemporary capitalism - in all its diversity.

\subsection{Labour Organising: Old and New Actors}

As mentioned earlier, from a Marxist perspective one could argue that the issues related to the commodification of labour form the basis of class struggle. The neo-commodification in platform capitalism, expressed in forms of technological and spatial fixes (Silver 2003), as well as tighter control over labour process (Gandini 2019; Moore and Joyce 2019), provoke growing resistance from workers. With neo-commodification being the novelty of platform capitalism, it remains an unknown quantity. However, as Moore and Joyce (2019) convincingly argue, labour studies can benefit from not viewing data and algorithm developments as a 'black box' (Pasquale 2015) - the fact that algorithms are skewed against the workers in a non-transparent way, with unilateral decisions about pay and conditions and the 'dropping' of workers from platforms, is one of the reasons why resistance is mounted against the platforms in the first place. In this way, the data technology is demystified and exposed as the 'structural antagonism' (Wood and Lehdonvirta 2019), or source of conflict. 
The emergence of organised resistance to platform capitalism has been hampered from the offset, with unions facing both practical and legal difficulties. The previously discussed issues of misclassification mean that 'self-employed' workers might be prevented from unionising on the basis of anti-trust legislation (De Stefano 2017), and the mystification of the employers further means that workers can sometimes lack the adequate counterpart to whom to address their complaints (Johnston and Land-Kazlauskas 2018). Finally, the physical separation of workers on platforms can seriously hinder the possibilities of creating communities and networks.

Nevertheless, there is an ever-increasing number of worker- and union-led responses. Both established and grassroots unions have been addressing these issues for the past couple of years (Lenaerts et al. 2018; Vandaele 2018). Even the practical difficulties of organising have been addressed to some extent, with some reports of online networking proving to be an asset (Cant 2019; Maffie 2020). These practical issues have been less significant when it comes to 'offline' gig work, performed in physical space.

The most visible and often discussed example is that of delivery bike riders (Chesta et al. 2019; Marrone and Finotto 2019; Tassinari and Maccarrone 2017). One notable case is reported from Italy, where practical difficulties of organising have been overcome with industrial action organised in several cities. Chesta et al. (2019) argue that this is due to the riders' specific 'visibility in urban space', which translated into the ability to influence consumers and threaten the companies' public image. Added to that were the possibilities of using the technology to connect riders and create a social space, necessary for organising. While such cases should not be overstated, as their success has been limited, it is important to stress that both the technology and the discursive powers of platforms can be harnessed by the other side as well.

Finally, there are examples that show how successful organising can also deal with the difficulty of not having a viable partner for negotiations. Such was the case of Uber in France (Lenaerts et al. 2018, pp. 70-1), where in 2016 after a succession of strikes by Uber drivers, organised in a syndicate and supported by larger trade unions, the government invited Uber to join the negotiations.

It has been noted that these forms of unions are not so much a novelty as a return to the old days of activist unions, before their institutionalisation in Western capitalist countries. In line with this, it is claimed that platform workers are not a different category of worker, but that they are open to unionisation as a means to defend their interests (Vandaele et al. 2019). However, as a consequence of neo-commodification, platform workers include groups which might have been underrepresented in traditional trade unions. As such, this presents an opportunity for both sides to cooperate (Vandaele et al. 2019). 
Such a bottom-up, grassroots response to neo-commodification could show that the existing actors and institutions have not adequately responded to the profound challenges of neo-commodification. Whether or not they adapt or get replaced will depend on contextual variables and power resources.

In conclusion, the neo-commodification of labour through platforms has provoked a response. Despite the difficulties, both traditional and new, grassroots forms of organising have been emerging. As we have argued that neo-commodification threatens not only the institutional systems around the SER but goes beyond it, commodifying labour even further, it is not surprising to see new actors and different types of struggles emerging. It is also reasonable to assume that the outcomes of these struggles will go beyond categories we are already familiar with. The labour of those who are failed by social protection, who are just entering the global labour market, and are forced to engage in hybrid forms of employment requires new representation and protection, a new social and political response to neo-commodification. This response, however, cannot be limited to preserving the status quo of SER and social protection, as we have argued that neo-commodification also goes beyond these categories. How far these new actors will go in their demands for decommodification is yet to be seen.

\section{CONCLUSION}

In this chapter we discussed two broad questions: the novelty of the process of platformisation and its consequences. We have attempted to frame this discussion within the theories of the commodification of labour. Taking as a starting point the historical specificity of labour under capitalism, we have explored the view of commodification as a dynamic and contradictory process, crucial for the accumulation of capital. Keeping this dynamic in mind, we have seen how the processes of Landnahme and the mechanism of the reserve army of labour push the further commodification of labour. While important insights into the nature of the welfare state and SER can be learned from a Polanyian perspective, we stressed how from a Marxist perspective commodification is a permanent source of struggle between labour and capital, and the decommodifying capacity of institutions - even if they are an outcome of a long struggle - can be overstated. This allows us to understand platform capitalism as a threat that goes beyond the current institutional embedding of labour.

The hallmarks of labour-mediating platforms that we explored in this chapter are the use of data technology and algorithmic management, coupled with exploiting legal grey zones and relying on strong discursive mystification. This combination not only undermines the foundations of the SER and social protection systems but also shapes the process of the neo-commodification of labour. The technological solutions offered by platforms enable a merging of 
the private and work spheres in such a way as to turn workers into a seemingly perfect (fictious) commodity. This is done on both a local level where labour markets are disrupted and regulation bypassed, pitching workers into intense competition, with little bargaining power or protection from existing institutions, and on a global level, where it creates a vast reserve army of labour competing for underpaid jobs. Thus, platform capitalism has an unprecedented potential for external and internal Landnahme, a disruption of existing labour relation systems, and a creation of novel areas of commodification and exploitation.

By looking at the consequences of the process of neo-commodification, we have seen how institutional systems have responded in a variety of ways. While these responses in some cases highlight existing conflicts, we have observed how they also generate novel responses from some new actors. Grassroots, activist unions around the globe have been tackling the issues of algorithmic control - showing that neo-commodification and the struggles around it have very real manifestations.

Therefore, our conclusion is that, while we can learn a lot about platforms through the application of 'old' concepts, they also present a novel development which brings to light new responses and new actors. While it is possible to endlessly draw comparisons between the aggressive commodification and grassroots resistance of old and current struggles, we have sought to provide a theoretical (re)conceptualisation which could inform further research.

Finally, with regard to the implications of neo-commodification, it is necessary to mention some limitations. Most importantly, the particular combination of old and new which we have explored so far does not lead us to propose a conclusion of a great discontinuity in the history of capitalism. Platform capitalism is better thought of as one of the trends within contemporary capitalism, whose longevity we are yet to discover, rather than a distinctive phase. Additionally, in this chapter we have investigated neo-commodification as a relentless drive towards turning human labour into a pure commodity; however, the underlying contradiction of capitalism means that this is never possible. Hence, this is by no means a prophetic argument about a future world of pure market relationships - these will always be embedded and contested at every step. But as neo-commodification seeks out new avenues, so does the class struggle. Organised labour requires new ideas to tackle new problems in order to turn the tide from neo-commodification to a new emancipatory future. Some glimpses of these potential futures are already visible. 


\section{NOTES}

1. Marx calls this 'freedom' of the worker as freedom in the double sense - 'he can dispose of his labour-power as his own commodity, and that on the other hand he has no other commodity for sale, is short of everything necessary for the realisation of his labour-power' (Marx 1976, pp. 272-3). Hence, unlike a slave who is him-/herself a commodity bought and sold by slave owners, a worker in capitalism sells the labour power he/she owns. But since this labour power is his/ her only commodity, their physical existence is dependent on selling this labour power, i.e. on commodification of labour. This 'freedom' of workers contains, as David Harvey put it, political and ideological ironies observable in many forms in contemporary society (Harvey 2010, p. 100).

2. A good illustration is the example of Deliveroo which was documented in the press - the company had devised an official vocabulary to be used in official communication in order to avoid suggesting the existence of any kind of employment relation (Butler 2017).

3. Some have called this an evasion of social responsibility, akin to tax evasion (Daugerild et al. 2019); another term used for this agenda is 'radical responsibilization' (Fleming 2017).

4. Self-employed without employees.

\section{REFERENCES}

Aloisi, A. (2015), 'Commoditized Workers: Case Study Research on Labor Law Issues Arising from a Set of on-Demand/Gig Economy Platforms', Comparative Labor Law \& Policy Journal, 37 (3), 653-90.

Andersen, R. (2019), 'Rechtbank Amsterdam: Deliveroo-koeriers hebben recht op arbeidscontract', accessed 6 September 2019 at https://www.volkskrant.nl/gs -b0c65055

Baccaro, L. and C. Howell (2017), Trajectories of Neoliberal Transformation: European Industrial Relations since the 1970s, Cambridge, New York and Port Melbourne: Cambridge University Press.

Berg, J., M. Furrer, E. Harmon, U. Rani and M. S. Silberman (2018), Digital Labour Platforms and the Future of Work: Towards Decent Pay in the Online World, Geneva: ILO.

Bergvall-Kåreborn, B. and D. Howcroft (2014), 'Amazon Mechanical Turk and the Commodification of Labour', New Technology, Work and Employment, 29 (3), 213-23.

Block, F. (2003), 'Karl Polanyi and the Writing of The Great Transformation', Theory and Society, 32 (3), 275-306.

Boes, A., T. Kämpf, T. Lühr, B. Langes and A. Ziegler (2017), 'Cloud \& Crowd: New Challenges for Labour in the Digital Society', TripleC: Communication, Capitalism \& Critique. Open Access Journal for a Global Sustainable Information Society, 15 (1), 132-47.

Bouget, D., D. Ghailani, S. Spasova, B. Vanhercke, Liser, Ose, Applica, European Commission and S. A. and I. Directorate-General for Employment (2017), Access to Social Protection for People Working on Non-Standard Contracts and as Self-Employed in Europe: A Study of National Policies 2017, Brussels: European Commission. 
Burawoy, M. (2010), 'From Polanyi to Pollyanna: The False Optimism of Global Labor Studies', Global Labour Journal, 1 (2), 301-13.

Butler, S. (2017), 'Deliveroo accused of "creating vocabulary" to avoid calling couriers employees', The Guardian, 5 April, accessed 9 December 2019 at https://www .theguardian.com/business/2017/apr/05/deliveroo-couriers-employees-managers

Cant, C. (2019), Riding for Deliveroo: Resistance in the New Economy, Chichester: Wiley.

Cherry, M. A. (2016), Beyond Misclassification: The Digital Transformation of Work, SSRN Scholarly Paper ID 2734288, Rochester, NY: Social Science Research Network, 18 February, accessed 5 April 2020 at https://papers.ssrn.com/abstract= 2734288

Chesta, R. E., L. Zamponi and C. Caciagli (2019), 'Labour Activism and Social Movement Unionism in the Gig Economy. Food Delivery Workers Struggles in Italy', PARTECIPAZIONE E CONFLITTO, 12 (3), 819-44.

Crouch, C. (2019), Will the Gig Economy Prevail? Cambridge, UK and Medford, MA: Polity Press.

Daugerild, I., C. Degryse and P. Pochet (eds) (2019), The Platform Economy and Social Law: Key Issues in Comparative Perspective. Etui Working Paper 2019.10, Brussels: ETUI.

De Stefano, V. (2017), 'Non-Standard Work and Limits on Freedom of Association: A Human Rights-Based Approach', Industrial Law Journal, 46 (2), 185-207.

Dølvik, J. E. and K. Jesnes (2018), Nordic Labour Markets and the Sharing Economy: Report from a Pilot Project, Nordic Council of Ministers.

Donini, A., M. Forlivesi, A. Rota and P. Tullini (2017), 'Towards Collective Protections for Crowdworkers: Italy, Spain and France in the EU Context', Transfer: European Review of Labour and Research, 23 (2), 207-23.

Dörre, K., S. Lessenich and H. Rosa (2015), Sociology-Capitalism-Critique, London and New York: Verso.

Drahokoupil, J. and A. Piasna (2017), 'Work in the Platform Economy: Beyond Lower Transaction Costs', Intereconomics, 52 (6), 335-40.

Esping-Andersen, G. (1990), The Three Worlds of Welfare Capitalism, Princeton, NJ: Princeton University Press.

ETUI (2020), 'European Trade Union Institute (ETUI) - France: Uber Drivers Are Employees, Says the French Court of Cassation', accessed 7 April 2020 at https:// www.etui.org/About-Etui/News/France-Uber-drivers-are-employees-says-the -French-Court-of-Cassation

Fabo, B., J. Karanovic and K. Dukova (2017), 'In Search of an Adequate European Policy Response to the Platform Economy', Transfer: European Review of Labour and Research, 23 (2), 163-75.

Fleming, P. (2017), 'The Human Capital Hoax: Work, Debt and Insecurity in the Era of Uberization', Organization Studies, accessed at https://doi.org/10.1177/ 0170840616686129

Fraser, N. (2014), 'Can Society be Commodities All the Way Down? Post-Polanyian Reflections on Capitalist Crisis', Economy and Society, 43 (4), 541-58.

Fudge, J. (2017), 'The Future of the Standard Employment Relationship: Labour Law, New Institutional Economics and Old Power Resource Theory', Journal of Industrial Relations, 59 (3), 374-92.

Gandini, A. (2019), 'Labour Process Theory and the Gig Economy', Human Relations, 72 (6), 1039-56. 
Garben, S. (2017), Protecting Workers in the Online Platform Economy: An Overview of Regulatory and Policy Developments in the EU - Safety and Health at Work, accessed 9 December 2019 at https://osha.europa.eu/en/publications/protecting -workers-online-platform-economy-overview-regulatory-and-policy-developments/ view

Greenfield, A. (2018), Radical Technologies: The Design of Everyday Life, New York and London: Verso.

Greer, I. (2016), 'Welfare Reform, Precarity and the Re-commodification of Labour', Work, Employment and Society, 30 (1), 162-73.

Harvey, D. (2007), A Brief History of Neoliberalism, Oxford and New York: Oxford University Press.

Harvey, D. (2010), A Companion to Marx's Capital, New York and London: Verso Books.

Harvey, D. (2015), Seventeen Contradictions and the End of Capitalism, London: Profile Books.

Jesnes, K. (2019), 'Employment Models of Platform Companies in Norway: A Distinctive Approach?', Nordic Journal of Working Life Studies, 9, accessed at https://doi.org/10.18291/njwls.v9iS6.114691

Jesnes, K., A. Ilsøe and M. J. Hotvedt (2019), 'Collective Agreements for Platform Workers? Examples from the Nordic Countries', Nordic Future of Work, Brief, 3.

Johnston, H. (2020), 'Labour Geographies of the Platform Economy: Understanding Collective Organizing Strategies in the Context of Digitally Mediated Work', International Labour Review, 159 (1), accessed at https://doi.org/10.1111/ilr.12154

Johnston, H. and C. Land-Kazlauskas (2018), Organizing On-Demand: Representation, Voice, and Collective Bargaining in the Gig Economy, Working Paper, 29 March, accessed 9 December 2019 at http://www.ilo.org/travail/whatwedo/publications/ WCMS_624286/lang--en/index.htm

Kalleberg, A. L. and M. Dunn (2016), 'Good Jobs, Bad Jobs in the Gig Economy', Members-Only Library, 20 (1-2), accessed 9 December 2019 at http://www .lerachapters.org/OJS/ojs-2.4.4-1/index.php/LERAMR/article/view/3093

Kilhoffer, Z., K. Lenaerts and M. Beblavý (2017), The Platform Economy and Industrial Relations: Applying the Old Framework to the New Reality, SSRN Scholarly Paper ID 3053826, Rochester, NY: Social Science Research Network, 7 August, accessed 15 December 2019 at https://papers.ssrn.com/abstract=3053826

Lenaerts, K., Z. Kilhoffer and M. Akgüç (2018), 'Traditional and New Forms of Organisation and Representation in the Platform Economy', Work Organisation, Labour \& Globalisation, 12 (2), 60-78.

Maffie, M. D. (2020), 'The Role of Digital Communities in Organizing Gig Workers', Industrial Relations: A Journal of Economy and Society, 59 (1), 123-49.

Marrone, M. and V. Finotto (2019), 'Challenging Goliath. Informal Unionism and Digital Platforms in the Food Delivery Sector. The Case of Riders Union Bologna', PARTECIPAZIONE E CONFLITTO, 12 (3), 691-716.

Marshall, A. and B. Gregory (2020), 'Coronavirus Exposes Workers to the Risks of the Gig Economy', Wired, accessed 13 April 2020 at https://www.wired.com/story/ coronavirus-exposes-workers-risks-gig-economy/

Marx, K. (1976), Capital: A Critique of Political Economy, London and New York: Penguin Books in association with New Left Review.

Moore, P. V. and S. Joyce (2019), 'Black Box or Hidden Abode? The Expansion and Exposure of Platform Work Managerialism', Review of International Political Economy, 27 (4), 1-23. 
Murgia, A. and V. Pulignano (2019), 'Neither Precarious nor Entrepreneur: The Subjective Experience of Hybrid Self-employed Workers', Economic and Industrial Democracy, 1-27. DOI: 10.1177/0143831X19873966.

Murgia, A., R. Bozzon, P. Digennaro, P. Mezihorak, M. Mondon-Navazo and P. Borghi (2020), 'Hybrid Areas of Work Between Employment and Self-Employment: Emerging Challenges and Future Research Directions', Frontiers in Sociology, 4, accessed at https://doi.org/10.3389/fsoc.2019.00086

Murillo, D., H. Buckland and E. Val (2017), 'When the Sharing Economy Becomes Neoliberalism on Steroids: Unravelling the Controversies', Technological Forecasting and Social Change, 125, 66-76.

Offe, C. (1985), Disorganized Capitalism: Contemporary Transformations of Work and Politics, Cambridge, MA: The MIT Press.

Offe, C. (2011), 'Capitalism', in International Encyclopedia of Political Science, Thousand Oaks, CA: SAGE Publications, Inc., pp. 187-93.

Offe, C. and J. Keane (1984), Contradictions of the Welfare State, London: Hutchinson.

Osborne, H. (2016), 'Uber loses right to classify UK drivers as self-employed', The Guardian, 28 October, accessed 7 April 2020 at https://www.theguardian.com/ technology/2016/oct/28/uber-uk-tribunal-self-employed-status

Pasquale, F. (2015), The Black Box Society: The Secret Algorithms That Control Money and Information, Cambridge, MA: Harvard University Press.

Paul, K. (2019), 'Gig economy: California bill granting employee status passes assembly', The Guardian, 30 May, accessed 5 April 2020 at https://www.theguardian.com/ us-news/2019/may/29/california-bill-gives-employee-status-to-contract-workers

Polanyi, K. (2001), The Great Transformation: The Political and Economic Origins of Our Time, Boston, MA: Beacon Press.

Rana, P. (2020), 'WSJ News Exclusive | Uber, DoorDash and others discuss fund for drivers affected by coronavirus', The Wall Street Journal, 8 March, accessed 13 April 2020 at https://www.wsj.com/articles/uber-doordash-and-others-discuss-fund -for-sick-drivers-11583641022

Rubery, J., D. Grimshaw, A. Keizer and M. Johnson (2018), 'Challenges and Contradictions in the "Normalising" of Precarious Work', Work, Employment and Society, 32 (3), 509-27.

Scholz, T. (2017), Uberworked and Underpaid: How Workers Are Disrupting the Digital Economy, Cambridge: Polity Press.

Schor, J. B. and W. Attwood-Charles (2017), 'The "Sharing" Economy: Labor, Inequality, and Social Connection on For-Profit Platforms', Sociology Compass, 11 (8), e12493.

Shibata, S. (2019), 'Gig Work and the Discourse of Autonomy: Fictitious Freedom in Japan's Digital Economy', New Political Economy, 25 (3), 1-17.

Silver, B. J. (2003), Forces of Labor: Workers' Movements and Globalization Since 1870, Cambridge: Cambridge University Press.

Söderqvist, F. (2017), 'A Nordic Approach to Regulating Intermediary Online Labour Platforms', Transfer: European Review of Labour and Research, 23 (3), 349-52.

Sprague, R. (2015), 'Worker (Mis)Classification in the Sharing Economy: Trying to Fit Square Pegs into Round Holes', ABA Journal of Labor \& Employment Law, 31 (1), 53-76.

Srnicek, N. (2016), Platform Capitalism, Cambridge and New York: Polity Press.

Standing, G. (2007), 'Labor Recommodification in the Global Transformation', in A. Buğra and K. Ağartan (eds), Reading Karl Polanyi for the Twenty-First Century, New York: Palgrave Macmillan. 
Streeck, W. (2017), Buying Time: The Delayed Crisis of Democratic Capitalism, 2nd edition, with a new preface, London and New York: Verso.

Sundararajan, A. (2016), The Sharing Economy: The End of Employment and the Rise of Crowd-Based Capitalism, Cambridge, MA: The MIT Press.

Tassinari, A. and V. Maccarrone (2017), 'The Mobilisation of Gig Economy Couriers in Italy: Some Lessons for the Trade Union Movement', Transfer: European Review of Labour and Research, 23 (3), 353-7.

Thelen, K. (2018), 'Regulating Uber: The Politics of the Platform Economy in Europe and the United States', Perspectives on Politics, 16 (4), 938-53.

Todolí-Signes, A. (2017), "The "Gig Economy": Employee, Self-employed or the Need for a Special Employment Regulation?', Transfer: European Review of Labour and Research, 23 (2), 193-205.

van Doorn, N. (2017), 'Platform Labor: On the Gendered and Racialized Exploitation of Low-Income Service Work in the "On-Demand" Economy', Information, Communication \& Society, 20 (6), 898-914.

Vandaele, K. (2018), Will Trade Unions Survive in the Platform Economy? Emerging Patterns of Platform Workers' Collective Voice and Representation in Europe, Brussels: European Trade Union Institute.

Vandaele, K., A. Piasna and J. Drahokoupil (2019), “"Algorithm Breakers" are Not a Different "Species": Attitudes Towards Trade Unions of Deliveroo Riders in Belgium', ETUI Research Paper-Working Paper.

Wood, A. and V. Lehdonvirta (2019), Platform Labour and Structured Antagonism: Understanding the Origins of Protest in the Gig Economy, SSRN Scholarly Paper ID 3357804, Rochester, NY: Social Science Research Network, 5 March, accessed 5 November 2019 at https://papers.ssrn.com/abstract $=3357804$

Wood, A. J., M. Graham, V. Lehdonvirta and I. Hjorth (2019), 'Networked but Commodified: The (Dis)Embeddedness of Digital Labour in the Gig Economy', Sociology, 53 (5). https://doi.org/10.1177/0038038519828906

Zekic, N. (2019), Contradictory Court Rulings on the Status of Deliveroo Workers in the Netherlands, accessed 6 December 2019 at https://research.tilburguniversity .edu/en/publications/contradictory-court-rulings-on-the-status-of-deliveroo-workers -in

Zhou, N. (2018), 'Foodora rider classed as employee and wins unfair dismissal case', The Guardian, 16 November, accessed 5 April 2020 at https://www.theguardian .com/business/2018/nov/16/foodora-riders-ask-government-to-sue-german-parent -over-unpaid-wages

Zuboff, S. (2019), The Age of Surveillance Capitalism: The Fight for the Future at the New Frontier of Power, London: Profile Books. 